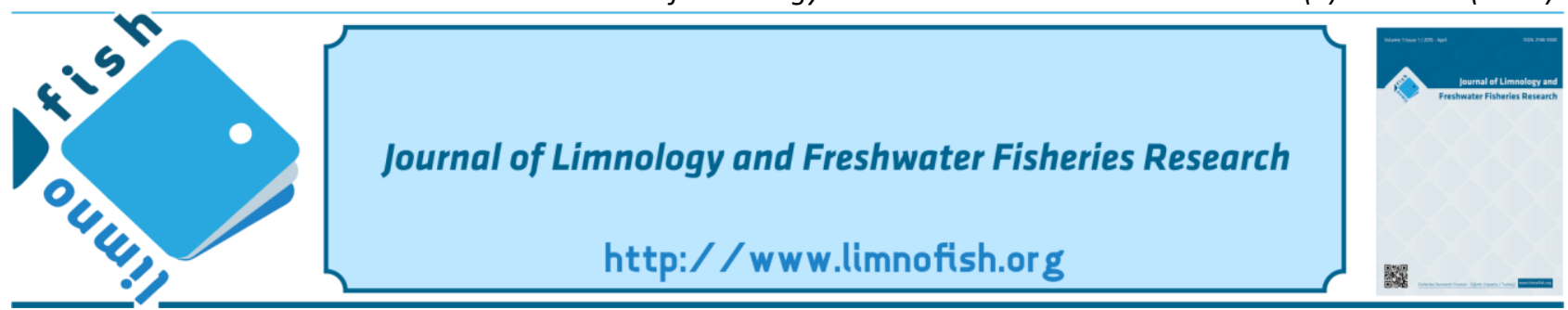

\title{
Water Quality Properties of Acı Lake and Meke Lake (Konya, Turkey)
}

\author{
Baran AŞIKKUTLU* (iD), Numan Emre GÜMÜŞ ${ }^{2}$ (D), Cengiz AKKÖZ ${ }^{1}$ (iD) \\ ${ }^{1}$ Department of Biology, Faculty of Science, Selçuk University, Konya, Turkey \\ ${ }^{2}$ Scientific and Technological Research and Application Center, Karamanoğlu Mehmetbey University, Karaman, Turkey
}

\section{A B STRACT}

Living beings need water to sustain their lives. Usage, conservation and management of water supplies are therefore extremely important. Researches on the investigation of the water quality properties of aquatic ecosystems are frequently carried out. The purpose of this study is to determine water quality characteristics of Ac1 Lake and Meke Lake. The lakes are located in Konya Province, Karapınar District and they are important habitats for birds and other species. In this study, some physical and inorganic parameters were examined in Ac1 Lake and Meke Lake at July 2014, October 2014 and January 2015. During the study, water samples were taken seasonally from the stations in the lakes. Results were compared with water pollution control regulation (SKKY) and water intended for human consumption standards (TS-266). According to Pearson Correlation Index (PCI) analysis, physical and inorganic parameters relationships were determined. About the measurement results of the physical and inorganic parameters, temperature values at July 2014 in two lakes, electrical conductivity values for all measurements in two lakes, dissolved oxygen and oxygen saturation values at July 2014 and October 2014 in Meke Lake and color values for all measurements in Meke Lake exceeded the limit values specified in the regulations, values other than these were found within the limit values of the regulation. According to PCI results, physical and inorganic parameters showed positive and negative correlation with each other in Acs Lake and Meke Lake.

\section{ARTICLE INFO}

\section{RESEARCH ARTICLE}

$\begin{array}{ll}\text { Received } & : 23.09 .2020 \\ \text { Revised } & : 27.01 .2021 \\ \text { Accepted } & : 02.02 .2021 \\ \text { Published } & : 30.12 .2021\end{array}$

DOI:10.17216/LimnoFish.799091

* CORRESPONDING AUTHOR

baranasikkutlu@selcuk.edu.tr Phone : +90332 2231871

Keywords: Ac1 Lake, inorganic parameters, Meke Lake, PCI, physical parameters

\section{Acı Göl ve Meke Gölü’ nün (Konya / Türkiye) Su Kalitesi Özellikleri}

Öz: Canlılar yaşamlarını sürdürmek için suya ihtiyaç duyarlar. Su kaynaklarının kullanımı, korunması ve yönetimi bu nedenle son derece önemlidir. Sucul ekosistemlerin, su kalitesi özelliklerinin araştırılmasına yönelik çalışmalar sıklıkla yapılmaktadır. Bu çalışmanın amacı, Acı Göl ve Meke Gölü'nün su kalitesi özelliklerini belirlemektir. Göller Konya İli Karapınar İlçesi'nde yer almaktadır ayrıca kuşlar ve diğer canlılar için önemli yaşam alanları durumundadırlar. Bu çalışmada, Temmuz 2014, Ekim 2014 ve Ocak 2015 tarihlerinde Acı Göl ve Meke Gölü'nde bazı fiziksel ve inorganik parametreler incelenmiştir. Çalışma sırasında göllerden belirlenen istasyonlardan, mevsimsel olarak su örnekleri alınmıştır. Sonuçlar, Su Kirliliği Kontrol Yönetmeliği (SKKY) ve İnsani Tüketim Amaçlı Sular Hakkında Yönetmeliğine göre (TS-266) karşılaştırılmıştır. Pearson Correlation Index (PCI) analizine göre fiziksel ve inorganik parametrelerin ilişkileri belirlenmiștir. İki gölde belirlenen fiziksel ve inorganik parametrelerden sicaklık değerlerinin Temmuz 2014'te iki gölde, elektriksel iletkenlik değerlerinin iki gölde yapılan tüm ölçümlerde, çözünmüş oksijen ve oksijen saturasyonu değerlerinin Temmuz 2014 ve Ekim 2014' te Meke Gölü’nde ve renk değerlerinin Meke Gölü'nde yapılan tüm ölçümlerde yönetmeliklerde belirtilen sınır değerleri aştığı belirlenmiştir, diğer değerler yönetmelik sınır değerleri içerisinde bulunmuştur. PCI sonuçlarına göre Acı Göl ve Meke Gölü'nde fiziksel ve inorganik parametreler birbirleriyle pozitif ve negatif korelasyon göstermiştir.

Anahtar kelimeler: Acı Göl, fiziksel parametreler, inorganik parametreler, Meke Gölü, PCI

How to Cite

Aşıkkutlu B, Gümüş NE, Akköz C. 2021. Water Quality Properties of Acı Lake and Meke Lake (Konya, Turkey). LimnoFish. 7(3): 260-270. doi: 10.17216/LimnoFish.799091

\section{Introduction}

The study of water resources that ensure the survival of living beings is an important issue. In
Turkey, studies on physical and chemical properties of water ecosystems have long been performed. In recent years, due to the increase in population 
density, environmental pollution has caused damage to life resources and ecosystem. (Al Naggar et al. 2018). Water resources are damaged by the increase in the use of fertilizers and pesticides as a result of the increase in land used for agriculture (Zalidis et al. 2002; Kumar et al. 2019). Nowadays, water pollution is a remarkable situation, because of this the effects of agricultural practices on the quality of the water bodies around them are an important issue (Evans et al. 2019; Toyama et al. 2020). Heavy metal pollution in waters is an important problem in developed and developing countries. Heavy metals are nondegradable elements that are added to aquatic systems through natural or anthropogenic processes. Anthropogenic resources are agriculture, industry and household waste, and it is a fact that these increase with the population. The presence of high levels of heavy metals can cause dangerous consequences for plants, animals and human associated with aquatic ecosystems (Goher et al. 2019). Studies are carried out in aquatic ecosystems, using statistical methods, to evaluate the relationships between physico-chemical results (Öztürk and Akköz 2014; Gümüş and Akköz 2020; Liu et al. 2020). Saline lakes around the world are generally under threat and are critical habitat for various migratory bird species. In addition, many microorganisms have adapted to life in high salt concentrations in these natural salt lakes. Most waterbirds have the ability to use salt lakes positively as nutrition. Changes in salinity rate can negatively affect the ability of these creatures to use these areas. However, there is little information about the ecosystem function of these water bodies. It is an important issue to examine the changes in these ecosystems for such reasons (Oren 2016; Senner et al. 2018).

Ac1 Lake, which is volcanic-based and a salty water source, is an important habitat for birds and other creatures (Akköz 2017a). Meke Lake, which came into existence as a result of the accumulation of water in an inactive volcano crater, and which includes various islets inside itself, has been added to the RAMSAR pact about the international protection of the aquatic places issue, at 21 June 2005 (Akköz 2017b). This study aims to determine the physical and inorganic parameters of the water samples taken from the three stations of Ac1 Lake and two stations of Meke Lake, that to evaluate the results obtained from them according to certain criteria.

\section{Materials and Methods}

\section{Properties of the Study Area}

Ac1 Lake, which is our research area, is $108 \mathrm{~km}$ north east of the regional capital, Konya and $8 \mathrm{~km}$ north east of Karapınar, close to the Adana Highway.
The source of the lake is rain and groundwater sources. Ac1 Lake water contains sulfur salts, giving it a salty and bitter taste. Ac1 Lake is one of the deepest lakes in the area, and is closest to Konya.

Meke Lake is located in Karapınar District at a distance of $106 \mathrm{~km}$ from Konya Province. In rainy times, the lake expands and in arid times the lake narrows also the alluvial lake bottom comes to exist. Meke Lake, which is volcanic-based and a salty water source, is an important habitat for birds and other creatures (Akköz 2017b). In this study, some physical and inorganic parameters were studied between July 2014 and January 2015 in these lakes.

\section{Sampling Stations}

Study materials were taken from stations capable of characterizing lakes for analysis. Satellite images of Ac1 Lake and Meke Lake sampling stations are given in Figure 1.

Sampling stations for Ac1 Lake;

Station 1: The station is located to the east of the lake. Its ground is covered with mud. Station coordinates; $37^{\circ} 42^{\prime} 42^{\prime \prime} \mathrm{N}, 33^{\circ} 40^{\prime} 23^{\prime \prime} \mathrm{E}$.

Station 2: The station is located to the north of the lake. Its ground is covered with mud. Station coordinates; $37^{\circ} 43^{\prime} 05^{\prime \prime} \mathrm{N}, 33^{\circ} 40^{\prime} 01^{\prime \prime} \mathrm{E}$.

Station 3: The station is located to the south west of the lake. Its ground is covered with small stones. Station coordinates; $37^{\circ} 42^{\prime} 40^{\prime \prime} \mathrm{N}, 33^{\circ} 39^{\prime} 38^{\prime \prime}$ E.

Sampling stations for Meke Lake;

Station 1: The station is located to the north of the lake. Its ground is covered with salt layer. Station coordinates; $37^{\circ} 41^{\prime} 08^{\prime \prime} \mathrm{N}, 33^{\circ} 38^{\prime} 44^{\prime \prime} \mathrm{E}$.

Station 2: The station is located east of the lake. Its ground is covered with salt layer. Station coordinates; $37^{\circ} 41^{\prime} 24^{\prime \prime} \mathrm{N}, 33^{\circ} 38^{\prime} 18^{\prime \prime} \mathrm{E}$.

\section{Determination of Water Quality}

Water samples were taken in July 2014, October 2014 and January 2015 from $0-20 \mathrm{~cm}$ surface waters, 0-5 $\mathrm{m}$ from the coastal part of the specified stations. Approximately $1 \mathrm{~L}$ samples from each station were poured into glass bottles for the measurement of physical and inorganic parameters and the bottles were taken to the laboratory immediately. Temperature, $\mathrm{pH}$, dissolved oxygen, oxygen saturation and electrical conductivity (according to $20^{\circ} \mathrm{C}$ ) parameters were instantly measured during sampling. Analyses of inorganic parameters ( $\mathrm{Al}, \mathrm{Co}$, $\mathrm{Cd}, \mathrm{Cr}, \mathrm{Cu}, \mathrm{Fe}, \mathrm{Mn}, \mathrm{Ni}, \mathrm{Pb}, \mathrm{Se}, \mathrm{Zn}$ ), were performed with ICP-OES device in Selçuk University Faculty of Agriculture, Laboratory of Soil Science and Plant Nutrition Laboratory.

Water samples that taken for the determination of the water quality of lakes were also assessed according to water pollution control regulation (SKKY 2015) and water intended for human 
consumption standards (TS-266 2005). SPSS 21.0 statistics package was used for the determination of the relationship between physical and inorganic parameters. Pearson Correlation Index (PCI) was applied on this program (Öztürk and Akköz 2014).

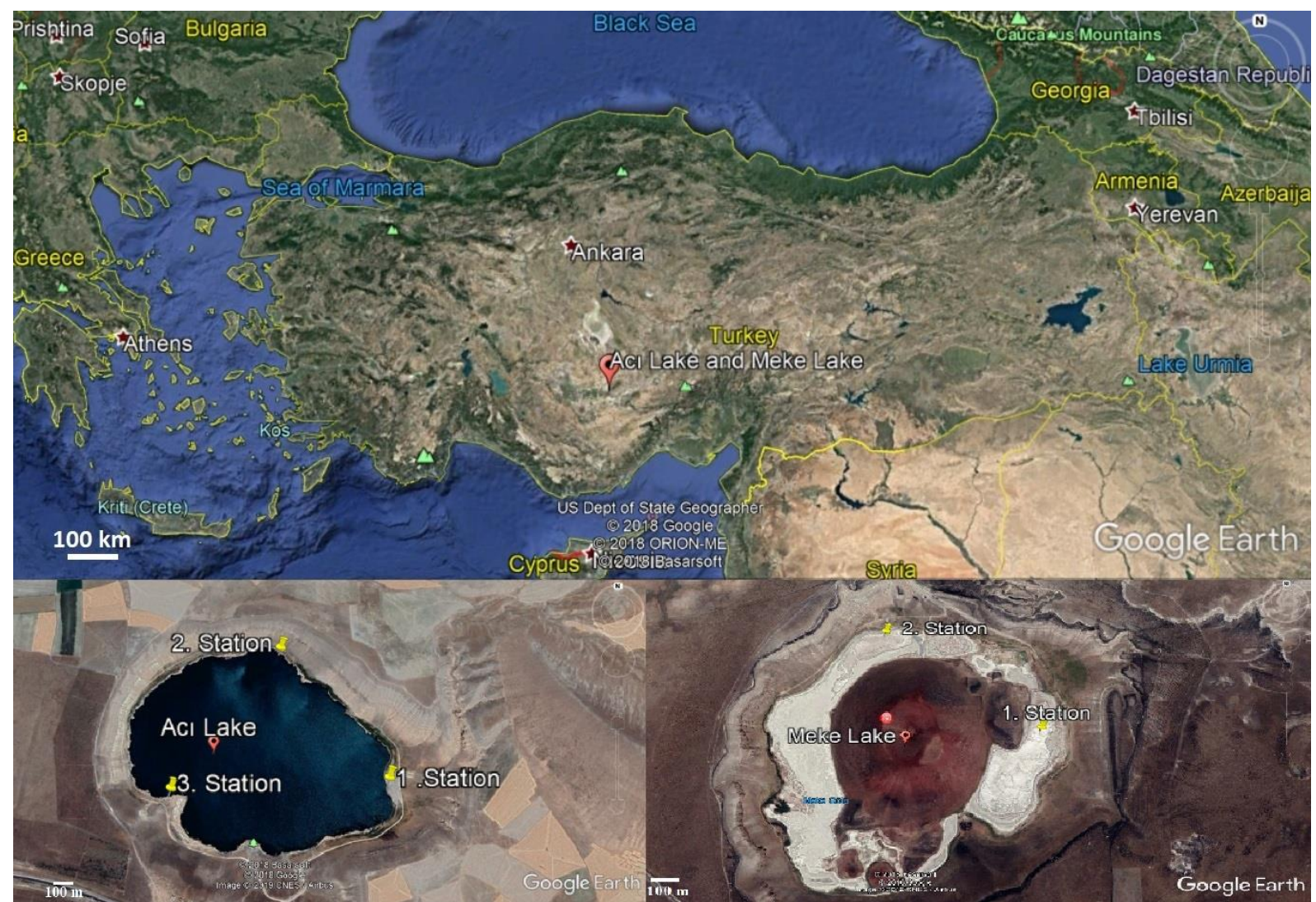

Figure 1. Satellite images of Ac1 Lake and Meke Lake sampling stations (Google 2018)

\section{Results}

Table 1. Seasonal physical and inorganic parameter levels in Ac1 Lake

\begin{tabular}{|c|c|c|c|c|c|c|c|c|c|}
\hline \multirow{2}{*}{$\begin{array}{l}\text { Season } \\
\text { Station }\end{array}$} & \multicolumn{3}{|c|}{ July 2014} & \multicolumn{3}{|c|}{ October 2014} & \multicolumn{3}{|c|}{ January 2015} \\
\hline & 1 & 2 & 3 & 1 & 2 & 3 & 1 & 2 & 3 \\
\hline Temperature $\left({ }^{\circ} \mathrm{C}\right)$ & 26.2 & 26.7 & 26.5 & 15.7 & 15.8 & 15.8 & 4.6 & 4.4 & 4.6 \\
\hline pH & 8.13 & 8.04 & 7.96 & 8.16 & 7.98 & 7.96 & 8.38 & 8.41 & 8.45 \\
\hline $\begin{array}{l}\text { Conductivity } \\
(\mu \mathrm{mhos} / \mathrm{cm})\end{array}$ & 75000 & 74200 & 73900 & 74800 & 73800 & 73500 & 148700 & 144600 & 150200 \\
\hline $\begin{array}{c}\text { Dissolved Oxygen } \\
(\mathrm{mg} / \mathrm{L})\end{array}$ & 10.89 & 10.14 & 8.06 & 7.89 & 7.9 & 7.9 & 8.38 & 8.41 & 8.45 \\
\hline Oxygen Saturation (\%) & 153.1 & 145.6 & 112.7 & 89.2 & 89.1 & 89.1 & 110.5 & 112.1 & 114.4 \\
\hline Color (Pt-Co) & 14 & 19 & 15 & 9 & 7 & 6 & 15 & 20 & 11 \\
\hline Al $(\mu \mathrm{g} / \mathrm{L})$ & BDL & BDL & BDL & BDL & BDL & BDL & BDL & BDL & BDL \\
\hline $\operatorname{Co}(\mu \mathrm{g} / \mathrm{L})$ & 0.001683 & BDL & 0.000341 & 0.001928 & 0.002387 & 0.002159 & 0.002622 & 0.002239 & 0.002088 \\
\hline$C d(\mu \mathrm{g} / \mathrm{L})$ & 0.000252 & 0.000097 & 0.000084 & 0.001091 & 0.000643 & 0.000967 & 0.000753 & 0.000447 & 0.000275 \\
\hline $\operatorname{Cr}(\mu \mathrm{g} / \mathrm{L})$ & BDL & BDL & BDL & 0.000342 & BDL & BDL & BDL & 0 BDL & BDL \\
\hline $\mathrm{Cu}(\mu \mathrm{g} / \mathrm{L})$ & BDL & BDL & BDL & BDL & BDL & BDL & BDL & BDL & BDL \\
\hline $\mathrm{Fe}(\mu \mathrm{g} / \mathrm{L})$ & 0.032843 & 0.032453 & 0.032942 & BDL & BDL & BDL & BDL & BDL & BDL \\
\hline $\operatorname{Mn}(\mu \mathrm{g} / \mathrm{L})$ & BDL & BDL & BDL & 0.007828 & 0.007619 & 0.007764 & 0.007375 & 0.033139 & 0.008139 \\
\hline $\mathrm{Ni}(\mu \mathrm{g} / \mathrm{L})$ & BDL & BDL & 0.001807 & 0.001662 & 0.001602 & 0.000041 & 0.000607 & BDL & BDL \\
\hline $\mathrm{Pb}(\mu \mathrm{g} / \mathrm{L})$ & BDL & BDL & BDL & BDL & BDL & BDL & BDL & BDL & BDL \\
\hline $\operatorname{Se}(\mu \mathrm{g} / \mathrm{L})$ & 0.001918 & BDL & BDL & BDL & 0.002417 & BDL & BDL & BDL & BDL \\
\hline $\operatorname{Zn}(\mu \mathrm{g} / \mathrm{L})$ & 0.034461 & 0.034276 & 0.035271 & 0.083559 & 0.062024 & 0.038633 & 0.011313 & BDL & 0.005277 \\
\hline
\end{tabular}

*BDL: below detection limit. 
Values for each seasonal measurement of the parameters belonging to some physical and inorganic analyses seasonally performed from July 2014 to January 2015 with surface water samples taken from the coastal area of Ac1 Lake are given in Table 1 and
Meke Lake are given in Table 2. Physical and inorganic parameters of Acı Lake and Meke Lake waters were determined and the qualities were evaluated according to the regulations of SKKY and TS-266.

Table 2. Seasonal physical and inorganic parameter levels in Meke Lake

\begin{tabular}{|c|c|c|c|c|c|c|}
\hline Season & July 2014 & & October 2 & & January 2 & \\
\hline Station & $\mathbf{1}$ & 2 & 1 & 2 & $\mathbf{1}$ & 2 \\
\hline Temperature $\left({ }^{\circ} \mathrm{C}\right)$ & 35.1 & 35.4 & 21 & 21 & 7 & 7.2 \\
\hline pH & 6.58 & 6.61 & 6.61 & 6.74 & 8.14 & 8.25 \\
\hline $\begin{array}{l}\text { Conductivity } \\
(\mu \mathrm{mhos} / \mathrm{cm})\end{array}$ & 108700 & 111800 & 114100 & 115500 & 71500 & 73700 \\
\hline $\begin{array}{l}\text { Dissolved Oxygen } \\
(\mathrm{mg} / \mathrm{L})\end{array}$ & 1.02 & 1.05 & 1.63 & 1.7 & 5.61 & 5.73 \\
\hline Oxygen Saturation (\%) & 16.5 & 17.1 & 23.2 & 22 & 50.3 & 52.8 \\
\hline Color (Pt-Co) & 314 & 386 & 151 & 168 & 22 & 26 \\
\hline $\mathrm{Al}(\mu \mathrm{g} / \mathrm{L})$ & BDL & BDL & BDL & BDL & BDL & BDL \\
\hline $\operatorname{Co}(\mu \mathrm{g} / \mathrm{L})$ & BDL & BDL & 0.003893 & 0.004036 & 0.002613 & 0.001208 \\
\hline $\mathrm{Cd}(\mu \mathrm{g} / \mathrm{L})$ & 0.001025 & 0.001071 & 0.000718 & 0.001298 & 0.002222 & 0.000558 \\
\hline $\operatorname{Cr}(\mu \mathrm{g} / \mathrm{L})$ & BDL & BDL & BDL & $\mathrm{BDL}$ & BDL & BDL \\
\hline $\mathrm{Cu}(\mu \mathrm{g} / \mathrm{L})$ & BDL & BDL & BDL & $\mathrm{BDL}$ & BDL & 0.006687 \\
\hline $\mathrm{Fe}(\mu \mathrm{g} / \mathrm{L})$ & 0.046981 & 0.048661 & BDL & BDL & BDL & BDL \\
\hline $\operatorname{Mn}(\mu \mathrm{g} / \mathrm{L})$ & BDL & $\mathrm{BDL}$ & 0.045101 & 0.05565 & 0.008695 & 0.008706 \\
\hline $\mathrm{Ni}(\boldsymbol{\mu g} / \mathrm{L})$ & BDL & 0.004889 & 0.003195 & 0.0056 & 0.003476 & BDL \\
\hline $\mathrm{Pb}(\mu \mathrm{g} / \mathrm{L})$ & $\mathrm{BDL}$ & $\mathrm{BDL}$ & $\mathrm{BDL}$ & 0.000055 & $\mathrm{BDL}$ & $\mathrm{BDL}$ \\
\hline $\operatorname{Se}(\mu \mathrm{g} / \mathrm{L})$ & 0.058341 & 0.065265 & BDL & $\mathrm{BDL}$ & 0.033695 & BDL \\
\hline $\mathrm{Zn}(\mu \mathrm{g} / \mathrm{L})$ & 0.048105 & 0.049223 & 0.106243 & 0.095935 & 0.011437 & 0.003114 \\
\hline
\end{tabular}

Relations between parameters determined in Ac1 Lake water and Pearson correlation coefficients given in the Table 3 and relations between parameters determined in Meke Lake water and Pearson correlation coefficients given in the Table 4. 
Table 3. Relations between parameters determined in Ac1 Lake water and Pearson correlation coefficients

\begin{tabular}{|c|c|c|c|c|c|c|c|c|c|c|c|c|c|c|}
\hline & Temperature & pH & Conductivity & $\begin{array}{c}\text { Dissolved } \\
\text { oxygen }\end{array}$ & $\begin{array}{c}\text { Oxygen } \\
\text { saturation }\end{array}$ & Color & Co & Cd & $\mathrm{Cr}$ & $\mathrm{Fe}$ & Mn & $\mathbf{N i}$ & Se & $\mathbf{Z n}$ \\
\hline Temperature & 1 & & & & & & & & & & & & & \\
\hline pH & -0.317 & 1 & & & & & & & & & & & & \\
\hline Conductivity & -0.810 & -0.299 & 1 & & & & & & & & & & & \\
\hline Dissolved oxygen & 0.047 & $0.933(* *)$ & -0.623 & 1 & & & & & & & & & & \\
\hline $\begin{array}{c}\text { Oxygen } \\
\text { saturation }\end{array}$ & -0.444 & $0.991(* *)$ & -0.166 & $0.875(*)$ & 1 & & & & & & & & & \\
\hline Color & 0.327 & 0.792 & $\left.-0.819{ }^{*}\right)$ & $0.959(* *)$ & 0.702 & 1 & & & & & & & & \\
\hline Co & -0.009 & $-0.946(* *)$ & 0.593 & $-0.999(* *)$ & $-0.892\left(^{*}\right)$ & $-0.948(* *)$ & 1 & & & & & & & \\
\hline Cd & $-0.991(* *)$ & 0.190 & $0.880(*)$ & -0.177 & 0.322 & -0.448 & 0.140 & 1 & & & & & & \\
\hline $\mathrm{Cr}$ & $-0.997(* *)$ & 0.317 & 0.810 & -0.047 & 0.444 & -0.327 & 0.009 & $0.991(* *)$ & 1 & & & & & \\
\hline $\mathrm{Fe}$ & 0.553 & $-0.966(* *)$ & 0.041 & -0.807 & $-0.992(* *)$ & -0.607 & $0.828(*)$ & -0.439 & -0.553 & 1 & & & & \\
\hline Mn & 0.761 & $-0.856\left(^{*}\right)$ & -0.237 & -0.612 & $-0.919(* *)$ & -0.363 & 0.641 & -0.670 & -0.761 & $0.9611^{(* *)}$ & 1 & & & \\
\hline $\mathrm{Ni}$ & $-0.817(*)$ & -0.287 & $0.998(* *)$ & -0.614 & -0.154 & $-0.812(*)$ & 0.583 & $0.886\left(^{*}\right)$ & $0.817(*)$ & 0.028 & -0.249 & 1 & & \\
\hline Se & -0.322 & $0.996(* *)$ & -0.294 & $0.931(* *)$ & $0.991(* *)$ & 0.789 & $-0.944(* *)$ & 0.195 & 0.322 & $-0.967(* *)$ & $-0.859\left(^{*}\right)$ & -0.282 & 1 & \\
\hline Zn & $-0.854\left(^{*}\right)$ & 0.764 & 0.387 & 0.480 & $0.845(*)$ & 0.212 & -0.512 & 0.779 & $0.854\left(^{*}\right)$ & $-0.906(*)$ & $-0.987(* *)$ & 0.399 & 0.768 & 1 \\
\hline
\end{tabular}

* Correlation is significant at the 0.05 level (2-tailed), ** Correlation is significant at the 0.01 level (2-tailed)

Table 4. Relations between parameters determined in Meke Lake water and Pearson correlation coefficients

\begin{tabular}{|c|c|c|c|c|c|c|c|c|c|c|c|c|c|}
\hline & Temperature & pH & Conductivity & Dissolved oxygen & $\begin{array}{c}\text { Oxygen } \\
\text { saturation }\end{array}$ & Color & Co & Cd & $\mathrm{Fe}$ & Mn & $\mathrm{Ni}$ & Se & $\mathbf{Z n}$ \\
\hline Temperature & 1 & & & & & & & & & & & & \\
\hline pH & $-0.882(*)$ & 1 & & & & & & & & & & & \\
\hline Conductivity & 0.807 & $-0.983(* *)$ & 1 & & & & & & & & & & \\
\hline Dissolved oxygen & $-0.919(* *)$ & $0.995(* *)$ & $-0.972(* *)$ & 1 & & & & & & & & & \\
\hline Oxygen saturation & $-0.929(* *)$ & $0.991(* *)$ & $-0.963(* *)$ & $0.999(* *)$ & 1 & & & & & & & & \\
\hline Color & $0.985(* *)$ & $-0.822(*)$ & 0.750 & $-0.868\left(^{*}\right)$ & $-0.880(*)$ & 1 & & & & & & & \\
\hline Co & -0.474 & 0.014 & 0.108 & 0.098 & 0.119 & -0.542 & 1 & & & & & & \\
\hline Cd & -0.263 & 0.293 & -0.341 & 0.299 & 0.260 & -0.230 & 0.189 & 1 & & & & & \\
\hline $\mathrm{Fe}$ & -0.542 & 0.664 & -0.602 & 0.640 & 0.661 & -0.501 & -0.201 & -0.492 & 1 & & & & \\
\hline Mn & $0.870(*)$ & -0.536 & 0.413 & -0.604 & -0.628 & $0.902(*)$ & $-0.829\left(^{*}\right)$ & -0.132 & -0.316 & 1 & & & \\
\hline $\mathbf{N i}$ & -0.167 & -0.301 & 0.442 & -0.230 & -0.204 & -0.246 & $0.909(*)$ & -0.097 & -0.221 & -0.627 & 1 & & \\
\hline Se & 0.131 & -0.343 & 0.420 & -0.317 & -0.324 & 0.189 & 0.482 & 0.401 & -0.587 & -0.121 & 0.510 & 1 & \\
\hline Zn & -0.005 & -0.252 & 0.384 & -0.237 & -0.244 & -0.032 & 0.557 & 0.124 & -0.200 & -0.316 & 0.725 & 0.562 & 1 \\
\hline
\end{tabular}

* Correlation is significant at the 0.05 level (2-tailed), ** Correlation is significant at the 0.01 level (2-tailed) 


\section{Discussion}

Extreme thermal regime changes in water bodies can alter biodiversity and ecological processes in the basin (Jiang et al. 2018). Temperature affects the chemical, physical and biological activities of water and changes the concentration of many factors. Metabolism, viscosity and respiratory rate of organisms in the water increases with temperature (Atıc1 2004). In our study, the average values for temperature measurements in Ac1 Lake were, 35.25 ${ }^{\circ} \mathrm{C}$ in July $2014,21^{\circ} \mathrm{C}$ in October 2014 and $7.1^{\circ} \mathrm{C}$ in January 2015 . The average values for temperature measurements in Meke Lake were, $26.5{ }^{\circ} \mathrm{C}$ at July $2014,15.8^{\circ} \mathrm{C}$ at October 2014 and $4.5^{\circ} \mathrm{C}$ at January 2015. Temperature was determined in second class quality at July 2014, in first class quality at October 2014 and January 2015 according to SKKY for Ac1 Lake. Temperature was determined in fourth class quality at July 2014, in first class quality at October 2014 and January 2015 according to SKKY for Meke Lake. In the study carried out in Saraydüzü Dam Lake, the water temperature was determined in the range of $1.8-21.7^{\circ} \mathrm{C}$ in water samples taken for a year (Kükrer and Mutlu 2019). In our study, it has been determined that the results except the values obtained from Meke Lake in July 2014 are similar to this study.

The $\mathrm{pH}$ in water is closely related to the amount of photosynthesis in the lake and the hydrogeological structure of the lake (Garg et al. 2010). The pH significance of the presence of metals in water and their release from sediment is well known (Kamzati et al. 2020). pH has potential importance in affecting global biogeochemical cycles for multiple elements (Stüeken et al. 2019). In our study, the average values for $\mathrm{pH}$ measurements in Ac1 Lake were obtained as, 8.04 at July 2014, 8.03 at October 2014 and 8.41 at January 2015. The average values for $\mathrm{pH}$ measurements in Meke Lake were obtained as, 6.6 at July 2014, 6.68 at October 2014 and 8.2 at January 2015. $\mathrm{pH}$ was determined in first class quality in all measurements according to SKKY and was determined within the limit values according to TS266 for both Ac1 Lake and Meke Lake. In the study conducted in Kovada Lake, $\mathrm{pH}$ values were determined between 6.98-10.2 (Çiçek and Yamuç 2017). Considering the average values, similar results were obtained in our study.

The conductivity value varies depending on the water temperature and the amount of dissolved material. Electrical conductivity increases accordingly with the increase of salinity in water (Geetha and Gouthami 2017; Mutlu et al. 2017). In our study, the average values for electrical conductivity measurements in Ac1 Lake were, 74367 $\mu$ mhos/ $\mathrm{cm}$ at July 2014, $74033 \mu \mathrm{mhos} / \mathrm{cm}$ at
October 2014 and $147833 \mu \mathrm{mhos} / \mathrm{cm}$ at January 2015. The average values for electrical conductivity measurements in Meke Lake were, $110250 \mu \mathrm{mhos} /$ $\mathrm{cm}$ at July 2014, $114800 \mu \mathrm{mhos} / \mathrm{cm}$ at October 2014 and $72600 \mu \mathrm{mhos} / \mathrm{cm}$ at January 2015. Electrical conductivity was determined in fourth class quality in all measurements according to SKKY. Electrical conductivity values were exceed the limit value in all measurements according to TS-266 for both Ac1 Lake and Meke Lake. Electrical conductivity was measured in the range of $230-860 \mu \mathrm{S} / \mathrm{cm}$ in the study conducted in Işık Lake (Aksever and Büyükşahin 2017). The obtained values in our study were found to be quite high compared to this study.

As a regulator of the metabolic events in water and an indicator of the condition of water, oxygen is the most significant chemical matter available in natural waters (Tanyolaç 2009). Dissolved oxygen is an important water quality parameter that indicates the oxygen reserve in water. The survival of most aquatic organisms depends on dissolved oxygen (Akankali et al. 2017). In a sunny day, in a water ecosystem that is free of winds and rich in nutrients, oxygen saturation can be measured as $200 \%$ or more as a result of the intense photosynthesis (Lampert and Sommer 2007). In our study, the average values for dissolved oxygen measurements in Ac1 Lake were, $9.7 \mathrm{mg} / \mathrm{L}$ at July 2014, $7.9 \mathrm{mg} / \mathrm{L}$ at October 2014 and $8.41 \mathrm{mg} / \mathrm{L}$ at January 2015. The average values for dissolved oxygen measurements in Meke Lake were, $1.04 \mathrm{mg} / \mathrm{L}$ at July 2014, $1.67 \mathrm{mg} / \mathrm{L}$ at October 2014 and $5.67 \mathrm{mg} / \mathrm{L}$ at January 2015. Dissolved oxygen and oxygen saturation values were found in first class quality at July 2014 and January 2015, second class quality at October 2014 according to SKKY for Ac1 Lake. Dissolved oxygen and oxygen saturation values were found in fourth class quality at July and October 2014 and third class quality at January 2015 according to SKKY for Meke Lake. Kükrer and Mutlu (2019) reported that dissolved oxygen values was detected in the range of 10.26$14.58 \mathrm{mg} / \mathrm{L}$ in water samples taken for a year from Saraydüzü Dam Lake. The values obtained in our study were found to be lower than this study.

Color may be due to natural metallic ions, humus, peat materials, algae, weeds or industrial wastes (Güler and Çobanoğlu 1997). In our study, the average values for color measurements in Acı Lake were, 16 Pt-Co at July 2014, 7.3 Pt-Co at October 2014 and 15.3 Pt-Co at January 2015. The average values for color measurements in Meke Lake were, 350 Pt-Co in July 2014, 159.5 Pt-Co in October 2014 and $24 \mathrm{Pt}-\mathrm{Co}$ in January 2015. Color values were found in second class quality in all measurements according to SKKY, also color values were under the limit value in all measurements according to TS-266 
for Ac1 Lake. Color values were found in fourth class quality at July 2014, third class quality at October 2014, second class quality at January 2015 according to SKKY, measurements were exceed the limit value in all measurements according to TS-266 for Meke Lake. In the study conducted about some water sources in the west of Turkey, color values were determined in the 1-39 Pt-Co range (Ozcelik 2016). In our study, some of the measurements made especially in Meke Lake were found to be much higher than this study.

The chemistry, biological availability, and toxicity of Aluminum (Al) in the aquatic environment are complicated, as well as affected by a wide range of water quality characteristics such as $\mathrm{pH}$, hardness and dissolved organic carbon (Cardwell et al. 2018). Aluminum values were found below the detection limits. Aluminum, was determined in first class quality in all measurements according to SKKY and was determined under the limit values according to TS-266 for both Ac1 Lake and Meke Lake. Aluminum was measured in the range of $2-77 \mu \mathrm{g} / \mathrm{L}$ in the study conducted in Işık Lake (Aksever and Büyükşahin 2017).

Cobalt (Co) is an essential element for human health. Overexposure has been shown to cause adverse health effects (Leyssens et al. 2017; Chen et al. 2020). Due to their long stay in nature, trace metals, including Cobalt, remain among the most studied environmental pollutants. Anthropogenic pollution of the environment by Cobalt is mainly due to mining and industrial activities (Collins and Kinsela 2010). In our study, the average values for cobalt measurements in Ac1 Lake were, $0.0007 \mu \mathrm{g} / \mathrm{L}$ at July 2014, $0.0022 \mu \mathrm{g} / \mathrm{L}$ at October 2014 and $0.0023 \mu \mathrm{g} / \mathrm{L}$ at January 2015. The average values for cobalt measurements in Meke Lake were, $0.0039 \mu \mathrm{g} /$ $\mathrm{L}$ at October 2014 and $0.0019 \mu \mathrm{g} / \mathrm{L}$ at January 2015. Cobalt values, were found in first class quality in all measurements according to SKKY for both Ac1 Lake and Meke Lake. In the study conducted in Kayalıköy Reservoir, cobalt was found to be $0.186 \pm 0.09 \mu \mathrm{g} / \mathrm{L}$ on average (Güher and Öterler 2020). The results we obtained in our study were found to be lower than this study.

Cadmium (Cd) has low permissible limits. It is a highly toxic heavy metal and has the potential to cause adverse health effects (Wu et al. 2016; Halwani et al. 2020). In our study, the average values for cadmium measurements in Ac1 Lake were, 0.0001 $\mu \mathrm{g} / \mathrm{L}$ at July 2014, $0.0009 \mu \mathrm{g} / \mathrm{L}$ at October 2014 and $0.0005 \mu \mathrm{g} / \mathrm{L}$ at January 2015. The average values for cadmium measurements in Meke Lake were, 0.001 $\mu \mathrm{g} / \mathrm{L}$ at July 2014, $0.001 \mu \mathrm{g} / \mathrm{L}$ at October 2014 and $0.001 \mu \mathrm{g} / \mathrm{L}$ at January 2015. Cadmium, was determined in first class quality in all measurements according to SKKY and was determined under the limit values according to TS-266 for both Acı Lake and Meke Lake. Cadmium was measured in the range of $0.05-0.18 \mu \mathrm{g} / \mathrm{L}$ in the study conducted in Iş1k Lake (Aksever and Büyükşahin 2017). When compared with the values obtained in our study, they found higher values than our results.

Chromium $(\mathrm{Cr})$ is considered to be one of the toxic heavy metals and its entry into water bodies is known to cause various disease effects (Sai Bhavya et al. 2019). In our study, chromium was detected as $0.0003 \mu \mathrm{g} / \mathrm{L}$ in the first station only at October 2014 in Ac1 Lake. Chromium has not been detected in Meke Lake. Chromium, was determined in first class quality in all measurements according to SKKY and was determined under the limit values according to TS-266 for both Ac1 Lake and Meke Lake. In the study conducted in Kayalıköy Reservoir, chromium was detected as an average of $2.786 \pm 3.00 \mu \mathrm{g} / \mathrm{L}$ (Güher and Öterler 2020).

Copper $(\mathrm{Cu})$ containing pesticides are widely used in agriculture to control certain diseases. The release of copper in large quantities to water and soil can have long-term detrimental consequences for the environment, organisms and ecosystem health (Kirk and Andreescu 2019). Copper was not detected in Ac1 Lake in our study. In Meke Lake, Copper was detected as $0.007 \mu \mathrm{g} / \mathrm{L}$ at the second station only at January 2015. Copper values, were found in first class quality in all measurements according to SKKY and were found under the limit values according to TS-266 for both Ac1 Lake and Meke Lake. Copper was measured in the range of $0.50-4.50 \mu \mathrm{g} / \mathrm{L}$ in the study conducted in Işı Lake (Aksever and Büyükşahin 2017).

Iron $(\mathrm{Fe})$ overload can cause major health problems such as liver cancer, liver cirrhosis, diabetes, infertility, heart and central nervous system diseases. The presence of high iron concentrations can affect the color, smell and taste of the water (Kumar et al. 2017). In our study, an average of $0.0327 \mu \mathrm{g} / \mathrm{L}$ was obtained at July 2014 for Ac1 Lake for iron measurements. In our study, an average of $0.0478 \mu \mathrm{g} / \mathrm{L}$ was obtained for Meke Lake for iron measurements at July 2014. Iron, was determined in first class quality in all measurements according to SKKY and was determined under the limit values according to TS-266 for both Acı Lake and Meke Lake. In the study conducted in Kayalıköy Reservoir, the average iron was found to be $0.142 \pm 0.09 \mathrm{mg} / \mathrm{L}$ (Güher and Öterler 2020). The values we obtained in our study were found to be lower than this study.

Manganese $(\mathrm{Mn})$ is an essential trace element found naturally in the environment. It is required as a cofactor for many enzymes and is important in many physiological processes. It supports development, 
growth and neuronal function. However, overexposure to Manganese may contribute to neurotoxicity and the development of Alzheimer's disease and Parkinson's disease (Martins et al. 2019). In our study, the average values for manganese measurements in Ac1 Lake were, $0.0078 \mu \mathrm{g} / \mathrm{L}$ at October 2014 and $0.0162 \mu \mathrm{g} / \mathrm{L}$ at January 2015. The average values for manganese measurements in Meke Lake were, $0.05 \mu \mathrm{g} / \mathrm{L}$ at October 2014 and $0.009 \mu \mathrm{g} / \mathrm{L}$ at January 2015. Manganese values, were determined in first class quality in all measurements according to SKKY, were determined under the limit values according to TS-266 for both Ac1 Lake and Meke Lake. Manganese was measured in the range of $0.12-70.35 \mu \mathrm{g} / \mathrm{L}$ in the study conducted in Işık Lake (Aksever and Büyükşahin 2017). The values we obtained in our study were found to be lower than this study.

Management of Nickel (Ni) contaminated soil and water is an important current environmental issue. The use of metal complexes in industry, agriculture and homes is one of the main causes of environmental pollution with nickel. Nickel is classified as an environmental pollutant and has toxic effects on plants, humans and food (Rathor et al. 2017). In our study, the average values for nickel measurements in Ac1 Lake were, $0.0006 \mu \mathrm{g} / \mathrm{L}$ at July 2014, $0.001 \mu \mathrm{g} / \mathrm{L}$ at October 2014 and $0.0002 \mu \mathrm{g} / \mathrm{L}$ at January 2015. The average values for nickel measurements in Meke Lake were, $0.002 \mu \mathrm{g} / \mathrm{L}$ at July 2014, $0.004 \mu \mathrm{g} / \mathrm{L}$ at October 2014 and $0.002 \mu \mathrm{g} /$ $\mathrm{L}$ at January 2015. Nickel values, were determined in first class quality in all measurements according to SKKY, were determined under the limit values in all measurement according to TS-266 for both Ac1 Lake and Meke Lake. In the study carried out in Saraydüzü Dam Lake, nickel was found to be $1.6 \mathrm{mg} / \mathrm{L}$ on average in water samples taken during a year (Kükrer and Mutlu 2019). The values we obtained in our study were found to be lower than this study.

Lead $(\mathrm{Pb})$ can enter water sources through installations containing lead. The effect of lead on neurodevelopmental effects in children, even at low doses, is well known (Levallois et al. 2018). In our study, the lead was not detected for Ac1 Lake. $0.000055 \mu \mathrm{g} / \mathrm{L}$ lead was measured for the Meke Lake in October 2014 at the second station. Lead values, were found in first class quality in all measurements according to SKKY and were found under the limit values according to TS-266 for both Ac1 Lake and Meke Lake. In the study conducted in Kayalıköy Reservoir, the average lead was determined as 0.873 $\pm 0.73 \mu \mathrm{g} / \mathrm{L}$ (Güher and Öterler 2020). The values we obtained in our study were found to be lower than this study.
Recent studies have shown that Selenium (Se) exhibits toxicity at high concentrations. In the study, it was stated that Selenium and Selenium nanoparticles in higher concentrations caused significant harmful changes in the histopathology, cellular and metabolic activities of Pangasius hypophthalmus fish species (Kumar et al. 2018). In our study, for selenium measurements, $0.0019 \mu \mathrm{g} /$ L was obtained for Ac1 Lake at the first station in July 2014 and $0.0024 \mu \mathrm{g} / \mathrm{L}$ at the second station in October 2014. In our study, for selenium measurements, the average values for Meke Lake were obtained as $0.061 \mu \mathrm{g} / \mathrm{L}$ in July 2014 and $0.016 \mu \mathrm{g} / \mathrm{L}$ in January 2015. Selenium values, were found in first class quality in all measurements according to SKKY and were found under the limit values according to TS-266 for both Ac1 Lake and Meke Lake. In the study conducted in Kayalıköy Reservoir, the average selenium was determined to be $7.046 \pm 5.56 \mu \mathrm{g} / \mathrm{L}$ (Güher and Öterler 2020). The values we obtained in our study were found to be lower than this study.

Zinc $(\mathrm{Zn})$ is known as the essential element for the survival of human life. The excessive discharge of zinc into water and soil causes water pollution and causes serious health problems such as septicemia, meningitis, iron deficiency anemia (Li et al. 2018). In our study, the average values for zinc measurements in Ac1 Lake were, $0.0346 \mu \mathrm{g} / \mathrm{L}$ at July 2014, 0.0614 $\mu \mathrm{g} / \mathrm{L}$ at October 2014 and $0.0055 \mu \mathrm{g} / \mathrm{L}$ at January 2015. The average values for zinc measurements in Meke Lake were, $0.048 \mu \mathrm{g} / \mathrm{L}$ in July 2014, $0.101 \mu \mathrm{g} /$ $\mathrm{L}$ in October 2014 and $0.007 \mu \mathrm{g} / \mathrm{L}$ in January 2015. Zinc, were found in first class quality in all measurements according to SKKY for both Ac1 Lake and Meke Lake. Zinc was measured in the range of $0.50-13.30 \mu \mathrm{g} / \mathrm{L}$ in the study carried out in Iş1k Lake (Aksever and Büyükşahin 2017). The values we obtained in our study were found to be lower than this study.

According to PCI Table 3, relations between parameters at 0.05 significance level that, temperature correlated negative with nickel and zinc. $\mathrm{pH}$ correlated negative with manganese. Conductivity correlated positive with cadmium and negative with color. Dissolved oxygen correlated positive with oxygen saturation. Oxygen saturation correlated positive with zinc, negative cobalt. Color correlated negative with nickel. Cobalt correlated positive with iron. Cadmium correlated positive with nickel. Chrome correlated positive with nickel and zinc. Iron correlated negative with zinc. Manganese correlated positively with selenium. Relations between parameters at 0.01 significance level that, temperature correlated negative with cadmium and 
chrome. $\mathrm{pH}$ correlated positive with dissolved oxygen, oxygen saturation and selenium, negative with cobalt and iron. Conductivity correlated positive with nickel. Dissolved oxygen correlated positive with color and selenium, negative with cobalt. Oxygen saturation correlated positive with selenium, negative with iron and manganese. Color correlated negative with cobalt. Cobalt correlated negative with selenium. Cadmium correlated positive with chromium. Iron correlated positive with manganese, negative with selenium. Manganese correlated negative with zinc.

According to PCI Table 4, relations between parameters at 0.05 significance level that, temperature correlated positive with $\mathrm{Mn}$ and negative with pH. pH correlated negative with color. Dissolved Oxygen correlated negative with color. Oxygen saturation correlated negative with color. Color correlated positive with manganese. Cobalt correlated positive with nickel and negative with manganese. Relations between parameters at 0.01 significance level that, temperature correlated positive with color, negative with dissolved oxygen and oxygen saturation. $\mathrm{pH}$ correlated positive with dissolved oxygen and oxygen saturation, negative with conductivity. Conductivity correlated negative with dissolved oxygen and oxygen saturation. Dissolved oxygen correlated positive with oxygen saturation.

As a results of our study, due to the salinity, some physical parameters results differ from the regulation values. According to Pearson Correlation Index, physical and inorganic parameters showed positive and negative correlation with each other in Ac1 Lake and Meke Lake. Some of the measurement results of the physical and inorganic parameters determined in Ac1 Lake and Meke Lake, temperature, electrical conductivity, dissolved oxygen and color, exceeded the values specified in the regulations, values other than these were found within the limit values of the regulation. Because of high amount of salt was observed in the water, it can be said that, lakes water can not be used for human consumption and the high level of physical parameters detected in lakes water depends on the environmental characteristics of the area where the lakes is located.

\section{References}

Akankali JA, Idongesit AS, Akpan PE. 2017. Effects of sand mining activities on water quality of OkoroNsit stream, NsitAtai local government area, Akwalbom state, Nigeria. IJDS. 6(7):451-462.

Akköz C. 2017a. The determination of some pollution parameters, water quality and heavy metal concentrations of Ac1 Lake (Karapınar/Konya, Turkey). Transylv Rev Syst Ecol Res. 19(1):1-18. doi: 10.1515/trser-2017-0001
Akköz C. 2017b. The benthic algae of Meke Lake (Karapınar/Konya). SDU-JEFF. 13(2):203-210.

Aksever F, Büyükşahin, S. 2017. Assessment of variations in water quality using statistical techniques: a case study of Işıklı Lake, Çivril/Denizli, Turkey. Arab J Geosci. 10(6):143. doi: 10.1007/s12517-017-2877-4

Al Naggar Y, Khalil MS, Ghorab MA. 2018. Environmental pollution by heavy metals in the aquatic ecosystems of Egypt. Open Acc J Toxicol. 3:555603.

doi: 10.19080/OAJT.2018.03.555603

Atıcı T. 2004. Sarıyar Barajı planktonik algleri kısım: I Cyanophyta. SDU-JEFF. 2(12):88-98.

Cardwell AS, Adams WJ, Gensemer RW, Nordheim E, Santore RC, Ryan AC, Stubblefield WA. 2018. Chronic toxicity of aluminum, at a $\mathrm{pH}$ of 6 , to freshwater organisms: Empirical data for the development of international regulatory standards/criteria. Environ Toxicol Chem. 37(1): 36-48.

doi: $10.1002 /$ etc.3901

Chen C, Xu C, Qian D, Yu Q, Huang M, Zhou L, Win JG, Chen L, Li E. 2020. Growth and health status of Pacific white shrimp, Litopenaeus vannamei, exposed to chronic water born cobalt. Fish Shellfish Immun. 100:137-145. doi: 10.1016/j.fsi.2020.03.011

Collins, RN, Kinsela, AS. 2010. The aqueous phase speciation and chemistry of cobalt in terrestrial environments. Chemosphere. 79(8):763-771. doi: 10.1016/j.chemosphere.2010.03.003

Çiçek NL, Yamuç F. 2017. Using epilithic algae assemblages to assess water quality in Lake Kovada and Kovada Channel (Turkey), and in relation to environmental factors. Turk J Fish Aquat Sc. 17(4):701-711. doi: 10.4194/1303-2712-v17_4_06

Evans AE, Mateo-Sagasta J, Qadir M, Boelee E, Ippolito A. 2019. Agricultural water pollution: key knowledge gaps and research needs. Curr Opin Env Sust. 36:20-27. doi: 10.1016/j.cosust.2018.10.003

Garg RK, Rao RJ, Uchchariya D, Shukla G, Saksena DN. 2010. Seasonal variations in water quality and major threats to Ramsagar Reservoir, India. Afr J Environ Sci Technol. 4(2):061-076.

Geetha S, Gouthami S. 2017. Internet of things enabled real time water quality monitoring system. Smart Water. 2(1):1-19. doi: 10.1186/s40713-017-0005-y

Goher ME, Ali MH, El-Sayed SM. 2019. Heavy metals contents in Nasser Lake and the Nile River, Egypt: An overview. Egypt J Aquat Res. 45(4):301-312. doi: 10.1016/j.ejar.2019.12.002

Google 2018. Google Earth. [Erişim tarihi: 15 Mar 2018]. Erişim adresi: https://www.google.com/earth/

Güher H, Öterler B. 2020. Seasonal change of physicochemical properties of Kayalıköy Reservoir (Kiklareli/Turkey) and determination of water quality. LimnoFish. 6(2):127-143. doi: 10.17216/limnofish.660975 
Güler Ç, Çobanoğlu Z. 1997. Su Kalitesi. Ankara: TC Sağlık Bakanlığı. $95 \mathrm{~s}$.

Gümüş NE, Akköz C. 2020. Investigation of water quality of Eber Lake (Afyonkarahisar). LimnoFish. 6(2):153-163. doi: 10.17216/limnofish.638567

Halwani DA, Jurdi M, Salem FKA, Jaffa MA, Amacha N, Habib RR, Dhaini HR. 2020. Cadmium health risk assessment and anthropogenic sources of pollution in Mount-Lebanon springs. Expos Health. 12(2):163-178. doi: 10.1007/s12403-019-00301-3

Jiang B, Wang F, Ni G. 2018. Heating impact of a tropical reservoir on downstream water temperature: a case study of the Jinghong Dam on the Lancang River. Water. 10(7):951. doi: 10.3390/w10070951

Kamzati LLJ, Kaonga CC, Mapoma HWT, Thulu FG, Abdel-dayem SM, Anifowose AJ, Chidya RCG, Chitete-Mawenda U, Sakugawa H. 2020. Heavy metals in water, sediment, fish and associated risks from an endorheic lake located in Southern Africa. IJEST. 17(1):253-266. doi: 10.1007/s 13762-019-02464-7

Kirk KA, Andreescu S. 2019. Easy-to-use sensors for field monitoring of copper contamination in water and pesticide-sprayed plants. Anal. Chem. 91(21): 13892-13899.

doi: 10.1021/acs.analchem.9b03385

Kumar V, Bharti PK, Talwar M, Tyagi AK, Kumar P. 2017. Studies on high iron content in water resources of Moradabad district (UP), India. Water Sci. 31(1):44-51. doi: $10.1016 /$ j.wsj.2017.02.003

Kumar N, Krishnani KK, Singh NP. 2018. Comparative study of selenium and selenium nanoparticles with reference to acute toxicity, biochemical attributes, and histopathological response in fish. Environ Sci Pollut R. 25(9):8914-8927.

Kumar V, Parihar RD, Sharma A, Bakshi P, Sidhu P.S, Bali AS, Karaouzas I, Bhardwaj R, Thukral AK, Gyasi-Agyei Y, Rodrigo-Comino J. 2019. Global evaluation of heavy metal content in surface water bodies: A meta-analysis using heavy metal pollution indices and multivariate statistical analyses. Chemosphere. 236:124364. doi: 10.1016/j.chemosphere.2019.124364

Kükrer S, Mutlu E. 2019. Assessment of surface water quality using water quality index and multivariate statistical analyses in Saraydüzü Dam Lake, Turkey. Environ Monit Assess. 191(2):71. doi: 10.1007/s10661-019-7197-6

Lampert W, Sommer U. 2007. Limnoecology: the ecology of lakes and streams. Oxford: Oxford University press. $324 \mathrm{p}$.

Levallois P, Barn P, Valcke M, Gauvin D, Kosatsky T. 2018. Public health consequences of lead in drinking water. Curr Environ Health Rep. 5(2):255-262. doi: 10.1007/s40572-018-0193-0

Leyssens L, Vinck B, Van Der Straeten C, Wuyts F, Maes L. 2017. Cobalt toxicity in humans-A review of the potential sources and systemic health effects. Toxicology. 387:43-56.

doi: 10.1016/j.tox.2017.05.015

Li Y, Wang X, Xu H, Xia P, Wang H, Jing H, Li J, Zhao J. 2018. High zinc removal from water and soil using struvite-supported diatomite obtained by nitrogen and phosphate recovery from wastewater. Environ Chem Lett. 16(2):569-573.

doi: 10.1007/s10311-017-0694-3

Liu T, Gao X, Zhang X, Li C. 2020. Distribution and assessment of hydrogeochemical processes of F-rich groundwater using PCA model: a case study in the Yuncheng Basin, China. Acta Geochim. 39(2):216-225. doi: 10.1007/s11631-019-00374-6

Martins AC, Morcillo P, Ijomone OM, Venkataramani V, Harrison FE, Lee E, Bowman AB, Aschner M. 2019. New insights on the role of manganese in Alzheimer's Disease and Parkinson's Disease. Int J Env Res Pub He. 16(19):3546. doi: 10.3390/ijerph16193546

Mutlu E, Yanık T, Sutan NA. 2017. Evaluation of the water quality of Topalyurdu Dam (Y1ldizeliSivas). Curr Trends Nat Sci. 6(12):277-286.

Oren A, 2016. Life in hypersaline environments. In: Hurst C, editor. Their world: A diversity of microbial environments. Advances in Environmental Microbiology, vol 1. Springer, Cham. p. 301-339.

Ozcelik M. 2016. Environmental pollution and its effect on water sources from marble quarries in western Turkey. Environ Earth Sci. 75(9):796. doi: 10.1007/s12665-016-5627-0

Öztürk BY, Akköz C. 2014. Investigation of water quality of Apa Dam Lake (Çumra-Konya) and according to the evaluation of PCA. Biodicon. 7 (2):136-147.

Rathor G, Chopra N, Adhikari T. 2017. Remediation of nickel ion from soil and water using Nano particles of zero-valent Iron (nZVI). Orient J Chem. 33(2): 1025-1029. doi: 10.13005/ojc/330259

Sai Bhavya K, Selvaran A., Samrot AV, Javad PTM, Appalaraju VVSS. 2019. Leather processing, its effects on environment and alternatives of chrome tanning. IJARET. 10(6):69-79. doi: 10.34218/IJARET.10.6.2019.009

Senner NR, Moore JN, Seager ST, Dougill S, Kreuz K, Senner SE. 2018. A salt lake under stress: Relationships among birds, water levels, and invertebrates at a Great Basin saline lake. Biol Conserv. 220:320-329. doi: 10.1016/j.biocon.2018.02.003

SKKY (Su Kirliliği Kontrol Yönetmeliği) 2015. Yüzeysel su kalitesi yönetimi yönetmeliğinde değişiklik yapılmasına dair yönetmelik. Yayımlandığı resmi gazete: Tarih 15 Nisan 2015, Resmi gazete no: 29327.

Stüeken EE, Martinez A, Love G, Olsen PE, Bates S, Lyons TW. 2019. Effects of $\mathrm{pH}$ on redox proxies in a Jurassic rift lake: Implications for interpreting environmental records in deep time. Geochim Cosmochim Ac. 252:240-267. doi: 10.1016/j.gca.2019.03.014 
Tanyolaç J. 2009. Limnoloji: Tatlı su bilimi. Ankara: Hatiboğlu Yayınevi 294 s.

Toyama H, Bessho K, Huang L, Hirota SK, Kano Y, Mase K, Sato T, Naiki A, Li J, Shimatani Y, Yahara T. 2020. The effects of water pollution on the phylogenetic community structure of aquatic plants in the East Tiaoxi River, China. Freshw Biol. 65(4):632-645.

doi: $10.1111 /$ fwb. 13451

TS-266. 2005. İnsani tüketim amaçlı sular. Türk Standartları Enstitüsü, Ankara, Türkiye.
Wu H, Liao Q, Chillrud SN, Yang Q, Huang L, Bi J, Yan B. 2016. Environmental exposure to cadmium: health risk assessment and its associations with hypertension and impaired kidney function. Sci Rep. 6(1):1-9. doi: 10.1038/srep29989

Zalidis G, Stamatiadis S, Takavakoglou V, Eskridge K, Misopolinos N. 2002. Impacts of agriculturial practires on soil and water quality in the Mediterrean region and proposed assesment methlodology. Agr Ecosyst Environ. 88(2):137-146. doi: 10.1016/S0167-8809(01)00249-3 